\title{
PERSEPSI MAHASISWA TERHADAP PRODUK MINUMAN FRESH TEA (STUDY KASUS MAHASISWA FAKULTAS EKONOMI UNIVERSITAS PGRI PALEMBANG)
}

\author{
Akila *)
}

\section{Abstrak}

Riset pemasaran merupakan kegiatan sistematis dalam rangka pengumpulan informasi, pencarian dan alanisa data untuk mengidintifikasi suatu masalah yang ada dalam perusahaan guna membantu manajemen dalam mengambil keputusan dan langkah selanjutnya dalam rangka meningkatkan pangsa pasar melalui perbaikan kualitas baik dari tingkat bahan baku, proses, pengendalian mutu, manajemen sampai produk akhir.

Instrumen menggunakan kuesioner, dimana berisi pertanyaan yang disebarkan kepada 91 mahasiswa Fakultas Ekonomi Universitas PGRI Palembang tentang produk, cara beli produk, seringnya membeli produk, kapan mereka membeli produk, apa yang menarik dari produk. Citrarasa menjadi daya tarik dari produk Fresh tea, hal ini dibuktikan dari 91 resonden, 54 responden (59,34\%) menyatakan yang menarik dari produk Fresh Tea adalah rasanya yang segar dan beraroma khas teh, 2 responden (2,20\%) menjawab tidak ada hal yang menarik, 21 responden $(23,08 \%)$ karena penampilannya yang menjadi daya tarik Fresh Tea sedangkan harga dan nilai gizi tidak memiliki kontribusi terhadap faktor daya tarik terhadap pembelian produk Ftesh Tea.

Dengan memperhatikan keterkaitan antara pemberian hadiah terhadap faktor ketertarikan terhadap pembelian produk maka pemberian hadiah di harapkan akan mampu menaikkan angka penjualan dari produk Fresh Tea.

Kata Kunci: riset pemasaran, produk

\section{A. PENDAHULUAN}

\section{Latar Belakang Penelitian}

Didalam pemasaran produk tidak selamanya akan berjalan dengan lancar sesuai dengan keinginan perusahaan. Banyak permasalahan yang akan timbul seperti keluhan, komentar, kritik, saran dan masukkan dari konsumen. Berbagai masukan yang membangun akan sangat membantu perusahaan dalam mengembangkan produk dan meningkatkan pangsa pasarnya. Permasalahan produk meliputi banyak aspek seperti kualitas produk (bentuk, rasa, warna, tekstur, aroma), harga, kemasan, ukuran produk dan ukuran kemasan, kemudahan penggunaan dan sebagainya, dimana berbagai permasalahan tersebut tidak akan dapat diselesaikan secara sendiri oleh perusahaan namun perlu bantuan konsumen terutama konsumen eksternal. Oleh karena itu untuk mengetahui kebutuhan dan keinginan konsumen terhadap suatu produk diperlukan suatu penelitian yang dinamakan riset pemasaran.

Perusahaan memiliki wawasan terhadap pasar, diantaranya konsep berwawasan produksi, konsep berwawasan produk, konsep berwawasan menjual dan konsep berwawasan pemasaran. Konsep berwawasan produksi berpendapat bahwa konsumen akan memilih produk yang mudah didapat dan memiliki harga yang murah. Perusahaan berkonsentrasi pada efesiensi produk yang tinggi dan cangkupan yang luas. Konsep berwawasan produk berpendapat bahwa konsumen akan memilih produk yang menawarkan mutu, kinerja terbaik. Perusahana berkonstrasi membuat produk yang baik dan terus

*) Dosen Tetap Fakultas Ekonomi UPGRI Palembang 
memperbaikinya. Konsep ini beranggapan bahwa konsumen akan membeli barang yang baik, namun lupa menanyakan kebutuhan konsumen sebenarnya. Konsep berwawasan menjual berpendapat bahwa jika konsumen dibiarkan saja, konsumen tidak akan membeli produk dalam jumlah yang cukup. Perusahan harus melakukan penjualan dan promosi agresif. Konsep berwawasan pemasaran berpendapat bahwa kunci untuk mencapai tujuan perusahaan terdiri dari penentuan kebutuhan adanya keinginan pasar sasaran serta memberikan kepuasan yang diinginkan secara lebih efektif dan efesien dari pada saingannya.

Ditahun-tahun ini, bisa dikatakan merupakan tahun bagi para pengusaha minuman kemasan. Karena banyaknya perusahaan yang memproduksi berbagai macam minuman mulai dari minuman energi, minuman isotonik, minuman bersoda dan lain-lain, sehingga muncul persainganpersaningan antar perusahan yang memproduksi minuman tersebut demi merebut hati para konsumen. Salah satu strategi pemasaran yang dilakukan ialah dengan memberikan hadiah bagi para pelanggan yang setia mengkonsumsi produk minuman dari perusahaan tertentu dengan sistem undian maupun hadiah langsung.

$$
\text { PT. Coca-cola Campany }
$$
merupakan salah satu diantara sekian banyak perusahaan yang menerapkan strategi ini. Perusahaan ini memberikan hadiah kepada para pelanggan, salah satunya di dalam kampus Universitas PGRI Palembang dengan sistem undian.

\section{Perumusan Masalah}

Permasalahan dalam penelitian ini adalah untuk menganalisa dalam riset pemasaran yaitu untuk menjawab pertanyaan" Apakah dengan menerapkan sistem pemberian hadiah kepada konsumen produk Fresh Tea mampu meningkatkan nilai jual di Fakultas Ekonomi Universitas PGRI Palembang ?"

\section{Kerangka Konsep}

Riset pemasaran adalah Perancangan, pengumpulan, analisis dan pelaporan data dan temuan secara sistematis, yang relevan dengan situasi permasalah tententu yang dihadapi perusahaan. Dalam kontribusi penelitian ini, maka penulis melakukan riset pemasaran dapat di lihat pada gambar 1 dibawah ini:

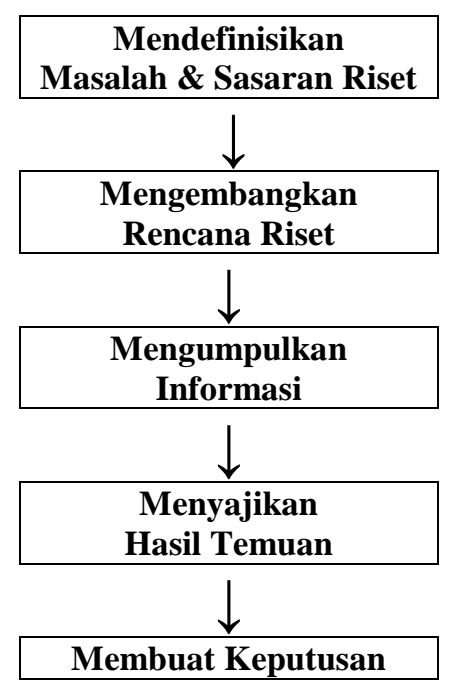

Gambar 1. Kontribusi Penelitian

\section{Definisi Operasional}

Riset pemasaran merupakan kegiatan sistematis dalam rangka pengumpulan informasi, pencarian dan alanisa data untuk mengidintifikasi suatu masalah yang ada dalam perusahaan guna membantu manajemen dalam 
mengambil keputusan dan langkah selanjutnya dalam rangka meningkatkan pangsa pasar melalui perbaikan kualitas baik dari tingkat bahan baku, proses, pengendalian mutu, manajemen sampai produk akhir.

Riset pemasaran adalah suatu penelitian yang dilakukan pada suatu produk apakah produk tersebut dibutuhkan dan telah memenuhi keinginan dari pelanggan atau konsumen yang meliputi banyak aspek seperti kualitas produk yang terdiri dari bentuk, rasa, warna, tekstur, aroma produk yang dihasilkan, harga, kemasan, ukuran produk dan ukuran kemasan, kemudahan penggunaan dan sebagainya.yang menjadikan konsumen loyal akan produk tersebut.

\section{B. TINJAUAN PUSTAKA \\ 1. Perilaku Konsumen}

Menurur Nugroho (2003:77), definisi perilaku konsumen adalah sesuatu proses pengambilan keputusan dan aktivitas masing-masing individu yang dilakukan dalam rangka evaluasi, mendapatkan penggunaan atau mengukur barang dan jasa.

Sedangkan menurut Bilson Simamora yang dikutip dari Engel $F$. James (2004:3), menyatakan bahwa Perilaku konsumen adalah tindakan yang langsung terlibat untuk mendapatkan, mengkonsumsi dan menghabiskan produk dan jasa termasuk proses keputusan yang mendahului dan mengikuti tidakan ini.

Dari definisi-definisi perilaku konsumen diatas, dapat ditarik kesimpulan sebagai berikut:

a. Perilaku

konsumen merupakan tindakan-tindakan yang dilakukan oleh individu, kelompok atau oleh organisasi tertentu. b. Tindakan ini berhubungan dengan proses pengambilan keputusan dari pada pembeli

c. Tujuannya adalah supya keputusan itu dapat digunakan untuk mendapatkan dan menggunakan barang dan jasa ekonomi.

\section{Model Perilaku Konsumen}

Dalam membantu para pemasar untuk merancang bauran pemasaran, menetapkan segmentasi, merumuskan, positioning dan perbedaan produk, memformulasikan analisis lingkungan bisnisnya, mengembangkan riset pemasarannya.

Selain itu, analisis perilaku konsumen juga memiliki peranan penting dalam merancang kebijakan publik. Bagi penguasa bidang ekonomi suatu negara memerlukan kajian ini untuk merumuskan kebijakannya dalam kerangka perlindungn konsumen.

Intinya, dengan mengetahui perilaku konsumen mungkin dapat dimanfaatkan untuk kepentingan pengembangan kemampuan seorang pemasar dalam menjalankan tugasnya.

\section{Pengertian Perilaku Beli Konsumen}

Menururt Swastha dan Handoko (2010:45) mengatakan bahwa Perilaku konsumen (pembeli) merupakan perilaku yang berkaitan dengan proses pemilihan produk yang akan dibeli, yang terdapat dalam proses pembelian. Perilaku konsumen dalam proses pembelian itu perlu dipelajari, sehingga dapat diketahui tindakan atau yang mendasari, melatar belakangi konsumen membeli suatu produk. Oleh karena itu Swastha dan Handoko (2010:46) mendefinisikan pula bahwa Perilaku konsumen merupakan tindakan 
seseorang atau individu yang langsung menyangkut pencapaian dan penggunaan produk (barang atau jasa) termasuk proses keputusan yang mendahului dan menentukan tindakan tersebut.

Perilaku konsumen menurut Enggel dan kawan-kawan yang dikutip oleh Umar (2008:77) adalah suatu tindakan yang langsung dalam mendapatkan, mengkonsumsi serta menghabiskan produk dan jasa, termasuk proses keputusan yang mendahui dan menyusuli tindakan tersebut.

Sedangkan menurut Schiffman dan Kanuk yang dikutip oleh Sumarwan (2004:88) yang mengatakan bahwa Perilaku konsumen diartikan sebagai perilaku yang diperlibatkan konsumen dalam mencari, membeli, menggunakan, mengevaluasi dan menghabiskan produk dan jasa yang mereka harapkan akan memuaskan kebutuhan mereka.

Dari perngertian perilaku konsumen ini dapat diketahui bahwa perilaku konsumen itu dimulai dari upaya konsumen untuk mencari produk atau jasa yang dibutuhkannya atau yang akan dibeli dan dikonsumsinya.

Dalam upaya mencari produk atau jasa yang dibutuhkan selanjutnya akan dibeli dan dikonsumsi, maka konsumen membutuhkan informasi tentang produk atau jasa tersebut. Setelah informasi jelas tentang produk dan jasa tersebut diperolehnya, maka selanjutnya dapat menentukan keputusan beli sebagi upaya untuk memanfaatkan atau menggunakan produk atau jasa tersebut.

Dalam kaitan dengan penelitian ini informasi yang dibutuhkan oleh mahasiswa yang dapat mempengaruhi perilaku belinya sebagai konsumen dapat dipengaruhi oleh orang lain maupun pengaruh media cetak dan elektronik, sehingga dapat menentukan keputusan konsumen untuk membeli atau tidak membeli produk.

\section{Faktor-Faktor Yang Mempengaruhi Perilaku Konsumen}

Menurut Bilson Simamora (2003:5), bahwa pilihan pembelian seseorang juga mempengaruhi oleh empat faktor perilaku konsumen yang utama, yaitu:

a. Motivasi, Kebanyakan dari kebutuhan yang ada tidak cukup kuat untuk memotivasi seseorang untuk bertindak pada suatu saat tertentu. Suatu kebutuhan akan berubah menjadi motivasi apabila kebutuhan itu telah mencapai tingkat tertentu.

b. Persepsi,Seseorang yang termotivasi siap bereaksi, bagaimana orang itu berindak akan mempengaruhi oleh persepsi mengenai situasi. Dua orang dalam kondisi motivasi yang sama dan tujuan situasi yang sama mungkin bertindak secara berbeda karena persepsi mereka terhadap situasi itu berbeda karena persepsi meraka terhadap situasi itu berbeda. Orang dapat memberikan persepsi yang berbeda terhadap rangsangan yang sama karena tiga proses persepsi, yaitu perhatian yang selektif, gangguan yang selektif dan mengingat kembali yang selektif

c. Proses Pembelajaran,Perubahan dalam perilaku seseorang yang timbul dari pengalaman dan kebanyakan perilaku manusia adalah hasil proses pembelajaran. Secara teori, pembelajaran seseorang dihasilkan melalui dorongan, rangsangan, isyarat, tanggapan dan penguatan. Bagi 
pemasar, mereka dapat membangun permintaan akan produk dengan menghubungkannya dengan dorongan yang kuat, dengan menggunakan isyarat motivasi dan dengan memberikan penguatan yang positif.

d. Kepercayaan dan Sikap,Melalui tindakan dan proses pembelajaran, orang akan mendapatkan kepercayaan dan sikap yang kemudian akan mempengaruhi perilaku pembeli. Kepercayaan adalah suatu pemikiran deskriptif yang dimiliki seseorang tentang sesuatu. Suatu sikap menjelaskan suatu organisasi dari motivasi, perasaan emosional, persepsi dan proses kognitif kepada aspek.

Sedangkan menurtut Kotler (2008:75), bahwa faktor-faktor yang mempengaruhi perilaku konsumen yaitu:

a. Faktor Budaya, Budaya merupakan penentu keinginan dan perilaku pembentukan paling dasar. Anakanak yang sedang tumbuh mendapatkan seperangkat nilai, persepsi, preferensi dan perilaku dari keluarga dan lembaga-lembaga penting lainnya. Masing-masing budaya dari sejumlah sub-budaya yang lebih menampakkan identifikasi dan sosialisasi khusus bagi para anggotanya. Sub-budaya mencakup kebangsaan, suku, agama, ras, kelompok bagi para anggotanya. Ketika sub-budaya menjadi besar dan cukup makmir, perusahaan akan sering merancang program pemasaran yang cermat disana.

b. Faktor Sosial, Selain faktor budaya, perilaku konsumen di pengaruhi oleh faktor-faktor sosial, seperti kelompok acuan, keluarga, peran dan status sosil. Kelompok acuan terdiri dari semua kelompok yang memiliki pengaruh langsung atau tidak langsung terhadap sikap atau perilaku orang tersebut. Keluarga nmerupakan organisasi pembeli konsumen yang paling penting dalam masyarakat dan para anggota keluarga menjadi kelompok acuan primer yang paling berpengaruh. Peran dan status sosial seseorang menunjukkan kedudukan orang itu setiap kelompok sosial yang ia tempati. Peran meliputi kegiatan yang diharapkan akan dilakukan oleh seseorang.

c. Faktor Pribadi, Keputusan membeli juga dipengaruhi oleh karakteristik pribadi. Karekteristik tersebut meliputi usia dan tahap dalam siklus hidup, pekerjaan, keadaan ekonomi, kepribadian dan konsep diri, juga nilai dan gaya hidup pembeli

d. Faktor Psikologi, Titik awal untuk memahami perilaku konsumen adalah adanya rangsangan pemasaran luar seperti ekonomi, teknologi, politik, budaya. Suatu perangkat psikologi berkombinasi dengan karakteristik konsumen tertentu untuk menghasilkan proses keputusan dan keputusan pembelian. Tugas pemasaran adalah memahami apa yang terjadi dalam kesadaran konsumen antara datangnya rangsangan pemasaran luar dengan keputusan pembelian akhir.

Empat proses psikologis (motivasi, persepsi, ingatan dan pembelajaran) secara fundamental, memengaruhi tanggapan konsumen terhadap rangsangan pemasaran. 


\section{PROSEDUR PENELITIAN}

\section{Sumber Data}

a. Data Primer, merupakan data yang langsung diambil dari sasaran penelitian (didapat dari sumber pertama) baik individu maupun perseorangan yaitu hasil kuesioner atau wawancara responden yang ada di Fakultas Ekonomi UPGRI Palembang

b. Data Sekunder, merupakan data primer yang telah diolah dan disajikan dalam bentuk tabel dan digunakan peneliti untuk diproses lebih lanjut dan data yang berasal dari literatur atau media baik cetak maupun elektronik seperti buku dan internet, dapat berupa dasar teori atau data-data lain yang mendukung.

\section{Pengambilan Populasi Dan Sampel} Menurut Sugiyono (2010:55) bahwa Populasi adalah wilayah generalisasi yang terdiri dari objek atau subjek yang mempunyai kuantitas dan karakteristik tertentu yang diterapkan oleh peneliti untuk dipelajari dan kemudian ditarik kesimpulannya. Adapun populasi dalam penelitian ini adalah seluruh mahasiswa Fakultas Ekonomi Universitas PGRI Palembang yang berjumlah 963 mahasiswa yang terdiri dari Jurusan Manajemen dan Akuntansi dengan perincian sebagai berikut:

Tabel 1

Jumlah Mahasiswa Fakultas

Ekonomi Univ. PGRI Palembang

\begin{tabular}{|c|l|c|}
\hline No & $\begin{array}{c}\text { Jurusan / } \\
\text { Program Studi }\end{array}$ & Jumlah \\
\hline $\mathbf{1}$ & Manajemen & 379 \\
$\mathbf{2}$ & Akuntansi & 594 \\
\hline & Jumlah & 963 \\
\hline
\end{tabular}

Sumber: TU FE Univ. PGRI Palembang 2015
Menurut Sugiyono (2010:65) bahwa Sampel adalah sebagian dari jumlah dan karakteristik yang dimiliki oleh populasi tersebut. Adapun mengingat terbatasan waktu, biaya tenaga dan lainnya, maka populasi tidak diteliti seluruhnya dalam hal ini, peneliti hanya mengambil sebagian dari populasi dengan syarat sifat dan karateristik mewakili populasi, sehingga data dan informasi yang didapat dari sebagian populasi dapat dipakai untuk menaksir populasinya.

Dalam penelitian ini teknik pengambilan sampel adalah propabilitas sampel dengan tipe random sampel. Secara rendom artinya setiap mahasiswa mempunyai kesempatan yang sama untuk dipilih sebagai sampel yang selanjutnya dijadikan sebagai responden. Dari populasi sebanyak 963 mahasiswa tersebut, peneliti mengambil sampel sebanyak 91 orang. Adapun jumlah sampel dihitung dengan menggunakan rumus solvin (Umar, 2008) sebagai berikut:

Sampel $(\mathrm{n})=N /\left(1+\left(N \cdot e^{2}\right)\right.$

Dimana:

$\mathrm{n}=$ Jumlah sampel

$\mathrm{N}=$ Jumlah populasi

$\mathrm{e}=$ tingkat kesalahan sebesar $10 \%$

karena kesalahan dalam pengambilan sampel yang masih dapat ditolerir atau diizinkan, diambil sebesar $10 \%$, maka besarnya sampel adalah:

$$
\text { Sampel } \begin{aligned}
(\mathrm{n}) & =963 /\left(1+\left(963 \times 0,1^{2}\right)\right. \\
& =90,59 \\
& =91 \text { responden }
\end{aligned}
$$

Dari jumlah sampel yang dihitung kemudian ditentukan perbandingan masing-masing sesuai dengan perbandingan mahasiswa perjurusan yaitu sebagai berikut: 
Tabel 2

Jumlah Sampel Mahasiswa Di Fakultas Ekonomi Univ. PGRI Palembang

\begin{tabular}{|c|l|c|c|}
\hline No & $\begin{array}{c}\text { Jurusan / } \\
\text { Program Studi }\end{array}$ & Proporsi & Sampel \\
\hline 1 & Manajemen & $(379 / 963) \times$ & 35 \\
2 & & 91 & 56 \\
& Akuntansi & $(594 / 963) \times$ & \\
\hline \multicolumn{3}{|c|}{ Jumlah } & 91 \\
\hline
\end{tabular}

Sumber: Data Olahan 2015

\section{Pendekatan Riset}

Pendekatan yang dilakukan oleh peneliti adalah dengan melakukan survey di Fakultas Ekonomi Universitas PGRI Palembang

\section{Instrumen Riset}

Instrumen yang digunakan untuk melakukan penelitian ini berupa kuesioner atau angket, yaitu cara pengumpulan data dengan memberikan atau menyebarkan daftar pertanyaan kepada responden, dengan harapan responden akan memberikan respon terhadap pertanyaan tersebut. Daftar pertanyaan bersifat tertutup, artiya alternatif jawaban telah disediakan dimana setiap kuesioner atau angket terdiri dari 12 pertanyaan.

\section{Metode Kontak}

Komunikasi yang terjadi dilakukan secara langsung kepada responden pada saat pembagian atau penyebaran angket.

\section{PEMBAHASAN PENELITIAN}

Pemasaran merupakan kegiatan tukar menukar atau jual beli barang dan jasa baik dilakukan oleh individu atau kelompok dalam waktu dan di tempat tertentu untuk memenuhi kebutuhan dan kepuasan. Riset pemasaran merupakan kegiatan sistematis dalam rangka pengumpulan informasi, pencarian dan alanisa data untuk mengidintifikasi suatu masalah yang ada dalam perusahaan guna membantu manajemen dalam mengambil keputusan dan langkah selanjutnya dalam rangka meningkatkan pangsa pasar melalui perbaikan kualitas baik dari tingkat bahan baku, proses, pengendalian mutu, manajemen sampai produk akhir.

Dalam kegiatan ini dilakukan riset pemasaran tentang pemberian hadiah kepada konsumen produk Fresh Tea yang merupakan salah satu produk PT. Coca-cola Company terhadap pangsa pasar atau nilai jual dari produk itu sendiri, apakah mendongkrak nilai jual atau sebaliknya, akan menjatuhkan nilai jual.

riset Instrumen yang digunakan dalam menggunakan kuesioner, dimana kuesioner berisi pertanyaan yang disebarkan kepada responden sebanyak 91 mahasiswa tentang produk, cara beli produk, seringnya membeli produk, kapan mereka membeli produk, apa yang menarik dari produk misalnya harga, rasa, nilai gizi dan penampilan kemasan. Citrarasa merupakan sesuatu yang menjadi daya tarik dari produk Fresh tea, hal ini dibuktikan dari 91 resonden, 54 responden atau 59,34\% menyatakan bahwa yang menarik dari produk Fresh Tea adalah rasanya yang segar dan beraroma khas teh, 2 responden 2,20\% menjawab tidak ada hal yang menarik dari produk Fresh Tea, 21 responden $23,08 \%$ karena penampilannya yang menjadi daya tarik Fresh Tea sedangkan harga dan nilai gizi tidak memiliki kontribusi terhadap faktor daya tarik terhadap pembelian produk Ftesh Tea. 
Disamping daya tarik yang dimilikinya, Fresh Tea juga mempunyai beberapa kekurangan yaitu 38 responden $41,78 \% \quad$ responden menyatakan harganya kurang menarik di lihat dari segi harga yang relative mahal bagi mahasiswa di fakultas Ekonomi, 2 responden 2,20\% menilai tidak terdapat hal yang kurang menarik dari produk Fresh Tea jika di lihat dari segi pengemasan, iklan dan lain-lain. Untuk penampilan sebanyak 29 responden $31,87 \%$ menyatakan adanya penampilan yang kurang menarik. Kemudian nilai gizi memiliki kontribusi sebanyak 2 responden 2,20\% terhadap faktor yang kurang menarik dan 38 responden $41,78 \%$ menilai rasa sebagai salah satu faktor yang kurang menarik produk Fresh tea. Dari pertanyaan "Apakah anda setuju dengan harga Fresh Tea yang ditawarkan sekarang?" Sebanyak 40 responden $43,96 \%$ menjawab setuju dan 51 responden $56,04 \%$ menjawab tidak setuju. Dengan demikian maka untuk penentuan harga perlu peninjauan ulang. Dari beberapa jawaban tersebut, maka dominan menyatakan bahwa harga Fresh Tea kurang menarik. Harga Fresh Tea sekarang umumnya tergolong mahal bagi kalangan mahasiswa Fakultas Ekonomi Universitas PGRI Palembang yang memiliki uang saku relative terbatas, sehingga bagi mahasiswa tersebut harga menjadi salah satu hal yang perlu diperhitungkan sebelum mereka membeli produk Fresh Tea. Oleh karena kelemahannya yang relative besar terutama harganya maka direncanakan produk Fresh Tea perlu meninjau kembali perubahan ulang terhadap harga jual produk Fresh Tea.

Setiap konsumen memiliki selera yang berbeda terhadap kemasan Fresh Tea yang akan datang. Sebanyak 58 responden 63,74\% menyatakan tidak tahu kemasan apa yang sesuai, 20 responden $21,98 \%$ memilih botol kaca, 60 responden 65,93\% tetap memilih botol plastik. Jadi dari pertanyaan tersebut diketahui bahwa sebagian besar konsumen setuju dengan kemasan botol plastik sebagai pengemasan produk Fresh tea. Botol plastik bening (plastik bening/plastik kue) dipilih karena beberapa kelebihan yaitu kemasannya yang terlihat dari luar secara transparan dan terlihat menyegarkan.

Dari pertanyaan"Apakah anda tahu bahwa PT. Coca-cola Campony akan memberikan hadiah kepada konsumen hanya dengan membeli produknya?. Sebanyak 33 responden $36,26 \%$ tahu dan 58 responden 63,74\% menjawab tidak tahu. Dengan demikian dapat dilihat jika kebanyakan pembeli tidak tahu. Dengan demikian dapat dilihat jika kebanyakan pembeli tidak begitu memperhitungkan ada tidaknya pemberian hadiah terhadap pembelian memperhitungkan ada tidaknya pemberian hadiah terhadap pembelian produk Coca-cola. Dari pertanyaan"Apakah anda tertarik dengan hadiah dari PT. Coca-cola Company yang ditawarkan kepada anda hanya dengan membeli produk Fresh TeaFresh Tea atau yang lainnya?" Sebanyak 60 responden $65,93 \%$ menjawab tertarik dan 31 responden $34,07 \%$ menjawab tidak tertarik. Dengan memperhatikan keterkaitan antara pemberian hadiah terhadap faktor ketertarikan terhadap pembelian produk maka pemberian hadiah di harapkan akan mampu menaikkan angka penjualan dari produk Fresh Tea.

Dari pertanyaan "Menurut anda, apakah sistem pemberian hadiah akan mendongkrak nilai jual Fresh Tea? 
Sebanyak 16 responden $17,58 \%$ menjawab tidak dan 25 responden $27,47 \%$ menjawab ya. Dengan demikian pemberian sistem hadiah mampu mendongkrk penjualan Freh Tea

\section{E. KESIMPULAN DAN SARAN}

1. Kesimpulan

Dari hasil riset pasar yang dilakukan dan dilaksanakan pada mahasiswa Program Studi Manajemen dan Akuntansi sebanyak 91 orang, maka dapat disimpulkan bahwa:

1. Rata-rata mahasiswa mengetahui dan berminat terhadap produk Fresh Tea, terutama rasanya yang menyegarkan apa lagi di minum dalam keadaan dingin

2. Rata-rata mahasiswa akan tetap berminat membeli produk Fresh Tea jika harganya di rubah ulang atau diturunkan

3. Pangsa pasar Fresh Tea akan meningkat dengan adanya pemberian hadiah, tidak hanya di Fakultas Ekonomi tetapi di Universitas PGRI Palembang pada umumnya serta sampai ke masyarakat umum lainnya.

\section{Saran}

Dengan sistem pemberian hadiah dan penentuan ulang harga produk fresh tea diketahui meningkatnya pangsa pasar, sehingga penulis menyarankan:

1. Perusahaan harus menentukan harga jual yang murah dan terjangkau oleh kalangan ekonomi kebawah

2. Pemberian hadiah merupakan total awal untuk meningkatkan pangsa pasarnya.
DAFTAR PUSTAKA

Bilson Simamora, 2003, Merancang Pasar Dengan Pemasaran Efektif Dan

Profitabel, Gramedia Pustaka Utama, Jakarta

Ghozali, Imam, 2006, Aplikasi Analisis Multivariat Dengan Program SPSS, Cetakan ke IV , Badan Penerbit Universitas Diponegoro, Semarang

Kotler, Phillip Gary Amstrong, 2009, Dasar-Dasar Pemasaran, Edisi 9 Jidil 1 dan 2 PT. Indeks Kelompok Gramedia, Jakarta 2008, Manajemen Pemasaran Edisi Mellenium, Jilid 2, Prenhallindo, Jakarta

Priyatno, Duwi, 2010, Paham Analisa Statistik Data Dengan SPSS, Mediakom, Yogyakarta

Pusat Penelitian Universitas PGRI Palembang, 2012, Pedoman Penelitian Dosen, Universitas PGRI, Palembang

Sumarwan, Ujang, 2004, Perilaku Konsumen Teori dan Penerapan Dalam Pemasaran, Penerbit PT. Ghalia Indonesia dengan MMA-IPB, Jakarta

Sugiyono. 2010. Statistik Untuk Penelitian, Cetakan ke-16, CV. Alfabeta, Bandung

Swastha, Basu DH dan Handoko, 2009, Dasar-Dasar Pemasaran, Edisi 9 Jilid 1 dan 2 , PT. Indeks Kelompok Gramedia, Jakarta

Umar, Husein, 2008, Metode Penelitian Aplikasi Dalam Pemasaran, Penerbit PT. Gramedia Pustaka Umum, Jakarta 